\title{
Exploration on the Path of Teaching Reform of Biochemistry Course in Higher Vocational Colleges in the New Era
}

\author{
Fu Dandan, Wu Qingjie, Liu Ruiting
}

Heze Medical College,Heze, 274000, Shandong, China

Keywords: Context of new era; Higher vocational education; Biochemistry Teaching

\begin{abstract}
Higher vocational colleges are high-level vocational and technical education schools developed in China in recent years. It started late, and there are many places to be improved in education research. In the context of the new era, the development of society has put forward new requirements for the teaching of higher vocational biochemistry courses. This paper analyzes the problems existing in the teaching of biochemistry in higher vocational colleges in the context of the new era, and uses the cooperative learning model in the construction stage to carry out reform and exploration to improve the quality of teaching. To achieve the goal of training high-tech applied talents.
\end{abstract}

\section{Introduction}

Higher vocational colleges are vocational and technical colleges that have been developed on the basis of secondary vocational colleges in China in recent years. Their research on education and teaching is still in the primary stage. Cooperative learning is more common in the research of basic education in China, and there are few studies about the teaching of higher vocational schools. Higher vocational colleges pay insufficient attention to teaching research, and most of the college teachers do not graduate from normal colleges. For example, medical biochemistry teachers are mostly medical graduates. Their knowledge of education and teaching is relatively weak and cannot meet the new requirements of education reform in the new era. It is necessary to speed up the exploration of new ways of teaching reform of biochemistry courses in higher vocational colleges in order to meet the requirements of talent training for social development and promote the rapid development of higher vocational education.

\section{Research on Biochemistry Course in Higher Vocational Education}

Biochemistry is a discipline that studies the chemical composition of organisms by using chemical theory and technology. Biochemistry is an important basic course in medical science. The research object is the human body. The characteristics of medical biochemistry course learning are abstract, complex, and poor in regularity, which are not conducive to students' learning and memory.

Biochemistry has a close relationship with various biology disciplines. Biochemistry includes medical biochemistry, basic biochemistry, and food biochemistry. Medical biochemistry belongs to the direction of animal biochemistry and it contributes to the prevention and treatment of common diseases. Biochemical theoretical methods have produced many fields of medical chemistry. The focus of food biochemistry is on mastering the basics of life sciences. It is of great significance to guide the transformation of food materials in biotechnology and chemical technology for the training of basic theory and research and development ability of subject talents. Biochemistry is a 
compulsory professional course for all relevant majors in higher vocational colleges. It plays an important role in Higher Vocational colleges.

The main task of the basic biochemistry course is to enable students to understand the complex metabolic laws of living organisms from a chemical point of view, and to cultivate students' scientific literacy and abilities to analyze and solve problems through scientific research. To improve students' scientific literacy, students are encouraged to understand the basic methods of scientific inquiry, so that they can acquire the basic knowledge of biochemistry required for further study and development, and thus improving students' comprehensive vocational ability.

The animal biochemistry course uses animals as research objects to study the material composition and structure of animals. It is an important basic course of animal medicine major. The goal of knowledge teaching is to enable students to grasp the changing laws of matter in the cell, and to grasp the molecular basis of genetics and the mechanism of biological regulation.

The Food Biochemistry course is an essential foundation for food nutrition and testing. It emphasizes the combination of classroom case teaching and after-school task orientation. The teaching goal is to develop students' ability to find problems and solve problems, and to lay a solid foundation for students to further study core professional courses, so that students can master the professional knowledge of food composition, structure and chemical changes in processing, and to lay a good foundation for follow-up professional courses. In summary, the teaching of biochemistry is a practical professional course. Its main teaching goal is to develop students' professional knowledge and to help them to master the ability to solve practical problems.

\section{Problems in the Teaching Reform of Biochemistry Courses in Higher Vocational in the New Period}

\subsection{Lack of teaching staff}

Biochemistry is the foundation of modern biology. Various life phenomena must be explored by means of the theoretical methods of biochemistry. The further development of the biology discipline depends on the progress of biochemistry research to a large extent. Biochemistry is the science of studying life chemistry. There are 28 majors offering biochemistry courses in Higher Vocational Colleges in China, and about 5000 teachers are engaged in biochemistry teaching in Higher Vocational colleges. The professional quality and quality of biochemistry teachers have a direct impact on the effectiveness of biochemistry teaching.

In recent years, China's higher vocational education has made great progress. In terms of the teaching staff, it has initially formed a teaching staff structure that combines theory with practice, and combines full-time with part-time teachers. The biochemistry course plays an important role in the food engineering majors and life science such as agricultural related majors in higher vocational colleges[1]. There are inevitably some problems in the large professional teachers who are engaged in the teaching of biochemistry.

The structure of biochemistry teachers in higher vocational colleges is too old, and the teachers' knowledge structure is aging, which cannot meet the needs of the rapid development of society for the transformation of talent training objectives. Some biochemistry teachers'educational ideas are obsolete, a few teachers lack professionalism, and the number of double-qualified teachers suitable for higher vocational education is insufficient. Strengthening the construction of teaching faculty in vocational biochemistry courses is the only way and effective strategy for curriculum reform in the new era.

Higher vocational education emphasizes the cultivation of practical ability. Higher vocational colleges are reformed and developed on the basis of secondary vocational education. Because of the 
influence of traditional teaching concepts, biochemistry teaching lacks enthusiasm for teaching. Higher vocational schools assign teachers to professional counterparts to participate in the management of production processes to improve teachers' practical teaching ability. However, due to objective conditions, the companies lack cooperation and enthusiasm, teachers can not achieve good results in the practice.

The overall age structure of biochemistry teachers in higher vocational colleges is older. Affected by the family economy and other reasons, they lack the awareness of self-improvement. The power of teachers' training stems from internal and external pressures. External pressure is the influence of curriculum reform, forcing teachers to carry out high-level academic education for degrees. The training of biotechnology teachers is mainly aimed at academic leaders and young teachers of professional courses. The ultimate goal is to solve the problem of titles and professional qualifications. Teacher training cannot play its effective driving force.

Higher vocational schools often attach importance to organizing and implementing teachers' centralized training. It is difficult to meet the individual development needs of teachers. The school education management is lacking, the university itself is weak, and there are differences among the teachers. The school only pays attention to the professional curriculum teacher training, and the teachers teaching biochemistry technology specialist basic course have fewer opportunities to go out for training.

The enrollment expansion of colleges and universities has resulted in a marked decline in the quality of students in higher vocational colleges. Some students have a poor cultural foundation in high school and lack the spirit of hard work. The social employment situation is grim. Higher vocational students have greater pressure on future employment and lack of learning motivation, which leads to the insufficient effective improvement of students' academic performance. It makes the teachers to be of professional boredom.

\subsection{The current teaching model is backward}

The characteristics of medical biochemistry knowledge learning are suitable for teaching in cooperative learning mode. The cooperative learning model is not limited by classroom learning, and it is remembered in the students' strong sense of autonomy. Medical biochemistry knowledge is difficult to remember. Cooperative learning can be supervised to help students with multiple studies in a group learning mode. Students can discuss with the same group of students at any time to deepen their understanding of the problem and promote students to learn to listen, express, evaluate, collaborate, etc., so that students' learning confidence and comprehensive quality are harmoniously developed.

The Medical Biochemistry course is an important foundation course for higher vocational medical and health majors. If the medical biochemical knowledge is insufficient, it will affect students' professional knowledge[1]. Traditional teaching methods cannot achieve good teaching results. Changing the teaching methods of medical biochemistry and improving the academic performance of students' medical biochemistry courses are important measures for teaching reform in higher vocational colleges.

The traditional teaching classroom is a competitive classroom, which is not conducive to the development of students' cooperative awareness and skills. Higher vocational education is a higher level of pre-employment education. Adopting traditional teaching methods is not conducive to improving teaching results. For students with low sense of responsibility and motivation, positive group pressure will be generated to improve their learning efficiency.

In the traditional teaching process, teachers often neglect the cultivation of students' cooperative skills. In the cooperative learning classroom, students should be trained in cooperative skills to 
achieve cooperative skills goals. In the traditional teaching classroom, the teacher is the subject of classroom teaching, and the students are in a passive learning state. In the cooperative learning mode, students become the masters of classroom learning, and the subjective status of students is reflected. The traditional form of teaching emphasizes that individual independent learning is the main form[3]. Individual independent learning is based on a large number of repeated exercises, making it difficult to achieve mutual progress.

\section{Analysis on the Path of Teaching Reform of Biochemistry Course in Higher Vocational Education in the New Period}

\subsection{Strengthen the construction of teaching staff}

Biochemistry teachers in higher vocational colleges should continue to learn and improve their professional qualities to meet the requirements of teaching reform and development in the new era. Colleges and universities should adopt various forms to strengthen the teacher's knowledge structure and ability literacy training. Regular hold education and training activities for teachers at all levels will enable teachers to change old educational concepts. Nutritional associations can be established to strengthen the links between biochemistry and nutrition, and nutrition experts can be hired as consultants to make the nutrition knowledge of biochemistry teachers more comprehensive.

By organizing teachers to go out to study, teachers' education and teaching level will be improved, and biopharmaceutical teachers will be encouraged to participate in the lecture contest of national bio-technology courses, so as to enhance their professional qualities. In order to meet the practical training equipment of biological pharmacy, we should cultivate students' practical ability in experiment.

Biochemistry teachers in higher vocational colleges must conscientiously study the basic content of the theoretical system of socialism with Chinese characteristics, learn to understand China's national conditions from the perspective of dialectical materialism, and clearly recognize the important mission of training high-skilled and high-quality talents, strive to become a practitioner of higher vocational education in China. Strive to become a practitioner of higher vocational education in China. Constantly improve their ideological and political quality, and promote the cultivation of students' Ideological and moral quality. Make them high-quality applied talents with certain professional theoretical knowledge and strong practical ability and strive to contribute to China's socialist modernization[4].

The knowledge structure of biochemistry teachers in higher vocational colleges is the basis for the formation of educational and scientific research capabilities. To improve the professional quality of biochemistry teachers in colleges and universities, it is necessary to make full use of the practice sites and off-campus teachers training bases in schools, and select teachers to internships in enterprises to improve teachers' perceptual insight into market demand trends and make corresponding teaching adjustments[5].

\subsection{Transform traditional teaching models}

The stage cooperative learning teaching mode has a greater role in promoting students' medical biochemistry courses. The orderly development of the cooperation stage provides students with a platform for learning and communication, and promotes the transformation of their learning style. In the stage cooperative learning teaching model, students are differentiated and complemented to form a heterogeneous group. Students with strong learning ability provide counseling and help to students with weak learning ability, and promote their understanding of the knowledge of chemical biology courses. Students with poor learning ability receive the help of teachers and classmates, 
actively adjust learning strategies, improve learning efficiency, and achieve the goal of students' common progress.

Cooperative learning emphasizes the principle of collective teaching and strives to reflect the unity of collectiveness and individuality. The teaching process strives to be clear and concise, and has a strong research nature. It emphasizes the joint learning based on individual student independent learning, and creates conditions for ensuring fair competition among the various groups.

Implementing cooperative learning in higher vocational colleges is of great significance for cultivating students' comprehensive quality. Learning to cooperate is the basic quality requirement of talents in modern society. The division of labor in contemporary society is refined, and competition and cooperation coexist. In the production of enterprises, all parts of the personnel must work together. The educational goal of higher vocational colleges is to train qualified technical talents. Therefore, students must have a sense of cooperation. In cooperative learning, the learning process should be discussed through group collaboration. The construction of knowledge needs to be improved and updated in cooperation and communication, which provides a strong guarantee for cultivating students' cooperative spirit.

The implementation of cooperative learning in higher vocational education must change the traditional teaching methods. In terms of the function of teaching methods, it relies on explicit knowledge and focuses on the direction of student ability development. In the structure of teaching methods, it transforms into encourage students to learn independently. In the guiding ideology of teaching method selection, it changes to the direction of encouraging students to internalize and absorb knowledge [6].

In the implementation of cooperative learning teaching mode in higher vocational education, it is necessary to change the traditional teaching concept, including the interactive view of traditional teaching, the goal view, the teacher-student view, the form view, the situation view and the evaluation view. At present, the schools adopt interactive teaching methods that are teacher-student interaction and lack of interaction among students. Cooperative learning enables effective interaction among students. The introduction of cooperative learning is of great significance to enhance student participation.

\section{Conclusion}

In the new era, the teaching of biochemistry courses in higher vocational colleges faces new problems. The lack of traditional teaching mode and teacher team construction is an important factor hindering the development of higher vocational biochemistry course teaching. In order to improve the teaching quality of biochemistry course in higher vocational colleges, to realize the educational goal of cultivating high-quality and high-skilled applied talents, and to make students better adapt to the requirements of social development in the new period, we must actively change the traditional teaching mode, strengthen the construction of Biochemistry teachers in Colleges and universities, and change the traditional teaching concept, adjust the student-oriented education concept, deepen the reform of teaching curriculum structure, better promote the reform and development of Biochemistry curriculum in Higher Vocational colleges, and cultivate high-quality skilled personnel adapting to the social development in the new period.

\section{References}

[1]Xuejing Li. Discussion on the Teaching of Biochemical Testing Course in Higher Vocational Education[J]. Journal of the modern occupation education,2018(14):80-81. 
[2]Junbei Xiang. Discussion on Teaching Design of Biochemistry Curriculum Project in Higher Vocational Education[J]. Science \& Technology Information, 2018, 16(10): 217-218.

[3]Yuzhen Li, Huaiqiu Xiao. Teaching Reform and Practice Exploration of "Biochemistry" Course in Higher Vocational Education[J]. Communication of Vocational education,2013(33):23-24.

[4]Wenjuan You, Yongjun Wen. Exploration and Practice of Teaching Reform of Biochemistry Course in Higher Vocational Education[J].Journal of Anhui Agricultural Sciences, 2009,37(32):16115-16116+16118.

[5]Bangqin Ding, Xin Qiu. Exploration on the Teaching Reform of the Integration of Inorganic and Analytical Chemistry Courses in Biotechnology and Applied Specialty[J]. Guangdong Chemical Industry,2007(07):142-144.

[6]Bing Liu. Research and Practice on the Curriculum Reform of Higher Vocational "Biochemistry" Based on “Teaching and Diagnosing”[J]. MING,2018(13):233. 